\title{
Auditor Industry Specialization and Market Valuation of Earnings and Earnings Components: Empirical Evidence from Companies Listed in Tehran Stock Exchange
}

\author{
Esmail Tavakolnia ${ }^{1,2}$ \& Seyed Vali Mostafavi Makrani ${ }^{3}$ \\ ${ }^{1}$ Faculty of Economics \& Administrative Science, Mazandaran University, Babolsar. Iran \\ ${ }^{2}$ Faculty of Management \& Accounting, Allameh Tabataba'i University, Tehran, Iran \\ ${ }^{3}$ Department of Accounting, Payam Noor University, Behshahr, Iran \\ Correspondence: Esmail Tavakolnia, Faculty of Economics \& Administrative Science, Mazandaran University, \\ Babolsar. Iran. Tel: 98-911-4701706
}

Received: October 9, 2015

Accepted: November 16, 2015

Online Published: November 17, 2015

doi:10.5430/afr.v4n4p187

URL: http://dx.doi.org/10.5430/afr.v4n4p187

\begin{abstract}
Financial statements play an important role in the world of accounting. They aim at providing information about financial position, performance, and changes in financial position of a company. Since the reliability of financial statements (including earnings and its components) depends on the audit quality to a large extent, understanding how market considers audit quality when valuating earnings and its components is of great importance. Thus, this study investigates the impact of auditor industry specialization, as a criterion for audit quality, on market valuation of earnings and earnings components. The sample of the study includes 155 firms listed in Tehran Stock Exchange over the 2006 to 2013 period, and the panel data regression method is used to process and test the hypothesis. The results indicate that market valuates earnings and its components (including total accruals, discretionary accruals, and operating cash flow) positively. Meanwhile, the moderating role of auditor industry specialization and audit firm's size was not verified in this valuation.
\end{abstract}

Keywords: Audit quality, Auditor industry specialization, Audit firm's size, Stock returns, Tehran Stock Exchange

\section{Introduction}

Accounting earnings includes accruals and cash flow components. Accruals components can be divided into discretionary and non-discretionary accruals. Dominant literature on earnings management considers discretionary accruals as opportunistic; a feature that undermines the information content of earnings (Habib et.al, 2014). Meanwhile, managers can also use discretionary accruals to signal confidential information, which are inaccessible for outsiders, to the market, and therefore, allow outsiders to assess the firm's future economic value better. Subramanyam (1996) reported a strong and direct relationship between stock returns and discretionary accruals, and concluded subsequently that discretionary accruals provide market with relevant information. Meanwhile, this relationship has not explained possible ways to increase information content of discretionary accruals. One of the possible ways is audit quality. Since the reliability of financial statements (including earnings and its components) depends on audit quality to a large extent, understanding how market considers audit quality when valuating earnings and its components is of great importance. Auditing also plays an important role in promoting and protecting shareholders' rights through discovering expropriation by insiders (Newman et.al, 2005) and can benefit management through signaling the reliability of financial information provided by management. It is expected that high quality auditors would separate components containing discretionary accruals information from components creating noise. This, in turn, will increase the information content of discretionary accruals (Krishnan, 2003). However, industry specialist auditors have more knowledge and experience than non-specialist auditors (Dunn and Mayhew, 2004). The findings of previous studies (Balsam et.al. 2003; Dunn and Mayhew, 2004) showed that auditor industry specialization has a positive effect on audit quality, and also industry specialist auditors can bring high-quality audit services to their clients. Thus, industry specialist auditors have an important role in monitoring financial reporting process. Industry specialist auditors can limit earnings management not only through financial statements auditing, but also through the interplay of internal corporate governance mechanisms, such as the Board of Directors (Habib et.al, 2014). 
Investigating the relationship between returns and earnings and earnings components of U.S firms, Krishnan (2003) concluded that discretionary accruals of firms audited by high-quality audit firms transmit management's confidential information which are useful for future returns forecasts. Mascarenhus et.al (2010) extend Krishnan (2003)'s study by adding auditor industry specialization as a criterion for audit quality, but fail to collect any evidence stating that discretionary accruals of firms audited by industry specialist auditors are valued positively.

In this study, the stream of studies are extended by using the data of listed firms in Tehran Stock Exchange. Iranian audit market is very competitive due to the active participation of a large number of small and medium-sized audit firms, compared to Western audit markets which are influenced by the power of Big 4 audit firms. While prior literature suggests that Big 4 audit firms have higher audit quality than other firms (Becjer et.al, 1993), it is not clear how stock market should value accounting information in a market dominated by domestic audit firms. Therefore, this study investigates the relationship between earnings and earnings components with stock returns, affected by auditor industry specialization.

\section{Review of the related literature}

\subsection{Valuating earnings and its components}

Earnings valuation has been a popular research topic over a long period. Accounting earnings includes accruals and cash flow. In a pioneering work, Jones (1991) developed a regression model for analyzing accruals in order to identify discretionary and non-discretionary accruals. Discretionary part of accounting accruals can be informative. Arab Mazar Yazdi et.al (2006) reported increasing information content of discretionary accruals compared to non-discretionary accruals in listed firms in Tehran Stock Exchange. It is also possible that discretionary accruals include some noise, such as opportunistic and aggressive reporting by managers (Healy and Palepu, 1993). Noise in discretionary accruals is inversely related to information content, and in fact the less the noise is, the more the information content will be. It is worth mentioning that Maham et.al (2013) also reported the inverse relationship between discretionary accruals and stock market returns in firms distributing share profit in listed firms in Tehran Stock Exchange. However, Rahnamaye Roodposhti et.al (2014) evaluated the relationship between earnings management with Tobin Q index and invested funds returns as positive. Therefore, capital market valuates earnings and its components.

\subsection{Auditor industry specialization}

Industry specialist auditors provide their clients with high-quality audit (Note 1) services, and hence increase accounting information quality. The reason is that industry specialist auditors have more knowledge and experience than non-specialist auditors (Balsam et.al. 2003; Dunn and Mayhew, 2004).

Balsam et.al (2003) examined the association between auditor industry specialization and earnings quality. They found out that auditor industry specialization has a negative relationship with the absolute value of discretionary accruals and a positive relationship with earnings response coefficient. Krishnan (2003) found out that the absolute value of discretionary accruals is higher for non-specialist auditors than for specialist auditors. This result is consistent with the argument that specialist auditors have more quality than non-specialist auditors.

Dunn and Mayhew (2005) examined how auditor industry specialization affects disclosure quality. They argued that auditor's selection by clients may be part of the disclosure strategy. They documented that auditor industry specialization has a positive relationship with employer's disclosure quality. Kwon et.al (2007) investigated the role of industry specialist auditors in international field. They found that firms with specialist auditors have less discretionary accruals and more earnings response coefficient.

In Iran, Etemadi et.al (2009) showed that firms with industry specialist auditors have less absolute value of discretionary accruals and higher earnings response coefficient compared to firms which do not have specialist auditors. In other words, industry specialist auditors present higher-quality audit to their clients. Tavakolnia et.al (2015) showed that auditor industry specialization and board independence have a negative and significant impact on earnings management. Also, the results of the study showed that the negative relationship between earnings management and board independence is weaker for firms audited by industry specialist auditors than firms audited by non-specialist auditors. Therefore, using industry specialist auditors could have a significant impact on earnings quality.

\subsection{Auditor industry specialization and valuating earnings and its components}

Auditors play an important role in reducing discretionary accruals noise resulting from opportunistic manipulation of accruals. Therefore, audit quality can affect discretionary accruals valuation. According to Krishnan (2003) information content of discretionary accruals should increase due to an increase in audit quality. 
Using the data from is Shanghai Stock Exchange, Gul et.al (2003) provided evidence indicating that market values earnings of firms audited by Top 10 local firms positively. However, they did not examine the valuation of earnings components. Sami (2008) and Zhou (2007) also provided evidence stating that after the implementation of new accounting standards in 1996 in China, information asymmetry has been reduced and firms listed in China Stock Exchange have experienced an increase in trading volume, prices fluctuation, and accounting information quality (reduction of earnings management and stock price synchronicity).

Moreover, Gul et.al (2003) examined the impact of audit quality on the influence of firm-specific information on stock price, as a criterion of stock price synchronicity. They concluded that an inverse relationship exists between audit quality and synchronicity, which indicated that high-quality audit would increase the influence of firm-specific information on stock price. Habib et.al (2014) confirmed positive valuation of earnings and its components by the market and stated that Big 4 audit firms play a significant role in valuating financial items by the market in order to benefit clients. In addition, they reported the negative impact of Top 10 local audit firms in China on earnings valuation. Due to the proximity of auditing environment in Iran and China (considering less market's proportion and creditors to audit reports), the result of Habib et.al (2014)'s study has the ability of being an acceptable citation for Iranian studies (Lin et.al, 2011; Tavakolnia et.al, 2014). Thus, according to the existing literature, it can be expected that using industry specialist auditors would influence earnings and earnings components valuation through affecting earnings quality and subsequently the relevance of earnings and earnings components. Given the above descriptions, the following hypotheses can be developed:

$\boldsymbol{H}_{1}$ : Auditor industry specialization influences market valuation of earnings.

$\boldsymbol{H}_{2}$ : Auditor industry specialization influences market valuation of earnings components.

\section{Methodology}

This is an applied study in terms of objective-based classification, and a correlation study in terms of methodology-based classification. Hence, multivariate regression method and default regression tests have been used.

\subsection{Population and sample}

The population of this study is all firms listed in Tehran Stock Exchange, and the sample has been selected through elimination method based on the following conditions:

1) The firm's financial information be available during the study; 2) be present in Stock during the study; 3) its fiscal year ends at the end of March; 4) be not among investment firms and banks, leasing and insurance; 5) has not changed its fiscal year during the study.

After eliminating firms which lack the mentioned criteria, 155 firms remained as the screened population of the study from among all firms listed in Tehran Stock Exchange, and their data for 8 years (2006-2013) were extracted from audited financial statements, Rah Avard Novin and Tadbir Pardaz softwares, as well as a software system designed by "Management of Research, Development and Islamic Studies of Stock Exchange" unit.

3.2 Variables and the model of the study

First, discretionary and non-discretionary accruals have been separated by using Jones' model (1991) (Dechow et.al, 1995; Kothari et.al, 2005). The following model has been estimated in listed firms in Tehran Stock Exchange.

$$
A C C_{i, t}=\alpha_{0}\left(1 / \text { Assets }_{i, t-1}\right)+\alpha_{1} \text { SSales }_{i, t}+\alpha_{2} \text { PPE }_{i, t}+\alpha_{3} \text { ROA }_{i, t}+\varepsilon_{i, t}
$$

Where:

$\mathbf{A C C}_{\mathbf{i}, \mathrm{t}}=$ total accruals of firm $\mathrm{i}$ in year $\mathrm{t}$, which is net profit minus operating cash flow;

Assets $_{\mathrm{i}, \mathrm{t}-1}=$ total assets of firm $\mathrm{i}$ in year $\mathrm{t}-$;

$\Delta \mathbf{S a l e s}_{\mathbf{i}, \mathrm{t}}=$ sales revenue of firm $\mathrm{i}$ in year $\mathrm{t}$ minus sales revenue of firm $\mathrm{i}$ in year $\mathrm{t}-1$;

$\mathbf{P P E}_{\mathbf{i}, \mathrm{t}}=$ account of properties, machineries, and equipment of firm $\mathrm{i}$ in year $\mathrm{t}$; and

$\mathbf{R O A}_{\mathbf{i}, \mathrm{t}}=$ return on assets of firm $\mathrm{i}$ in year $\mathrm{t}$, which is the ratio of net profit to total assets.

All the variables of this model have been divided by total assets of the beginning of the year.

The rest of the model indicates discretionary accruals. Non-discretionary accruals will be total accruals minus discretionary accruals, as follows:

$$
N D A=A C C-D A
$$

Where: 
NDA $=$ non-discretionary accruals

$\mathbf{A C C}=$ total accruals

DA= discretionary accruals

Then, in order to test capital market valuation of earnings and its components the following models, which are adopted from Habib et.al (2014) model, are used.

$$
\begin{aligned}
& R E T_{i, t}=\alpha_{0}+\alpha_{1} \operatorname{EARN}_{i, t-1}+\varepsilon_{i, t} \\
& R E T_{i, t}=\alpha_{0}+\alpha_{1} A C C_{i, t-1}+\alpha_{2} O C F_{i, t-1}+\varepsilon_{i, t} \\
& R E T_{i, t}=\alpha_{0}+\alpha_{1} D A_{i, t-1}+\alpha_{2} N D A_{i, t-1}+\alpha_{3} O C F_{i, t-1}+\varepsilon_{i, t}
\end{aligned}
$$

Where:

$\mathbf{R E T}_{\mathbf{i}, t}=$ return on assets of firm $\mathrm{i}$ in year $\mathrm{t}$, which is the sum of cash dividend and the difference of stock price at the end of the current year and the previous year, divided by stock price at the end of the previous year;

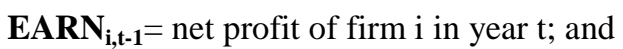

$\mathbf{O C F} \mathbf{F}_{\mathrm{i}, \mathrm{t}-1}=$ operating cash flow of firm $\mathrm{i}$ in year $\mathrm{t}-1$.

The definition of other variables have been presented in previous models. It is noteworthy that independent variables of the model have also been divided by total assets of the beginning of the year.

Then, auditor industry specialization is inserted into the model, which is adopted from Habib et.al (2014) model.

$$
\begin{gathered}
R E T_{i, t}=\alpha_{0}+\alpha_{1} \operatorname{EARN}_{i, t-1}+\alpha_{2} A I S_{i, t-1}+\alpha_{3} E A R N^{*} A I S_{i, t-1}+\varepsilon_{i, t} \\
R E T_{i, t}=\alpha_{0}+\alpha_{1} A C C_{i, t-1}+\alpha_{2} O C F_{i, t-1}+\alpha_{3} A I S_{i, t-1}+\alpha_{4} A C C^{*} A I S_{i, t-1}+\alpha_{5} O C F^{*} A I S_{i, t-1}+\varepsilon_{i, t} \\
R E T_{i, t}=\alpha_{0}+\alpha_{1} D A_{i, t-1}+\alpha_{2} N D A_{i, t-1}+\alpha_{3} O C F_{i, t-1}+\alpha_{4} A I S_{i, t-1}+\alpha_{5} D A^{*} A I S_{i, t-1}+\alpha_{6} N D A^{*} A I S_{i, t-1}+\alpha_{7} O C F^{*} A I S_{i, t-1}+ \\
\varepsilon_{i, t}
\end{gathered}
$$

Where:

$\mathbf{A I S}_{\mathrm{i}, \mathrm{t}-\mathrm{I}}=$ auditor industry specialization of firm $\mathrm{i}$ in year $\mathrm{t}$, and this study has used market share as an index for auditor industry specialization; because it shows priority of industry to other auditors. The more the auditor's market share is, the more the auditor industry specialization and experience compared to other rivals will be. Having a dominant market share indicates that the auditor has successfully differentiated himself from other rivals in terms of audit quality. Auditors' market share is calculated as follows:

Total assets of all clients of any particular audit firm in a particular industry

Total assets of all clients in this industry

In this study, firms which have a market share (i.e. the above equation) greater than [1.2* (the number of existing firms. 1)] are considered as industry specialist. After calculating the market share of an audit firm, if the obtained amount from the above equation is greater than the above equation, the audit firm is specialist in that industry. Therefore, if the auditor is industry specialist, s/he takes number one, otherwise it is zero (Habib and Bhaiyan, 2011).

\section{Findings of the study}

The data from 155 firms of the sample during 2006 to 2013 were extracted from data bases and transferred to Excell software. After necessary calculations for dependent and independent variables, necessary information for required statistical test were stored in appropriate files and processed in Eviews7 and SPSS17 softwares.

Before data analysis, the reliability of variables must be assessed. The reliability of variables means that the mean and variance of variables over time and covariance of variables during different years have been constant. As a result, the use of variables in the model will not result in false regression. Therefore, Im, Pesaran, and Shin's test was used. The results of the test are desirable and the significance level for all variables is less than 0.05 , and thus, all the variables of the study are reliable during the period of the study.

The next test which has been used is co-linearity test. Co-linearity is a situation indicating that an independent variable is a linear function of other independent variables. To calculate co-linearity, the indices of tolerance and inflation variance factor have been used. The less the tolerance is (close to zero), the information about variables would be less and problems would occur in using the variables. Variance inflation factor is also opposite the tolerance, and the variance of the regression coefficients increase by its increase. The desirable amount for variance inflation factor is less 
than 10. It is noteworthy that the amounts of tolerance and variance inflation factor were also quite desirable. To test the hypotheses, based on the results of Chaw test, panel data approach was used.

The results of estimates of models three and six have been presented in Table 1 in order to assess the impact of firm's earnings on its stock returns, as well as on the moderating effect of auditor industry specialization.

Table 1. Estimates of models three and six

\begin{tabular}{|c|c|c|c|c|}
\hline Variable & Coefficient & Significance & Coefficient & Significance \\
\hline Intercept & 0.033 & 0.072 & -0.009 & 0.823 \\
\hline Net profit & 0.755 & 0.000 & 1.208 & 0.000 \\
\hline Auditor industry specialization & - & - & 0.062 & 0.2 \\
\hline $\begin{array}{l}\text { Net profit* auditor industry } \\
\text { specialization }\end{array}$ & - & - & -0.572 & 0.066 \\
\hline \multicolumn{5}{|c|}{ Model three } \\
\hline F statistics $=41.749$ & & \multicolumn{3}{|c|}{ Adjusted R-square $=0.252$} \\
\hline Significance level $=0.000$ & & \multicolumn{3}{|c|}{ Durbin-Watson statistics $=2.051$} \\
\hline Significance level of Chaw test $=0.000$ & & \multicolumn{3}{|c|}{ Significance level Hauseman test $=0.000$} \\
\hline \multicolumn{5}{|c|}{ Model six } \\
\hline F statistics $=14.032$ & & \multicolumn{3}{|c|}{ Adjusted R-square $=0.251$} \\
\hline Significance level $=0.000$ & & \multicolumn{3}{|c|}{ Durbin-Watson statistics $=2.042$} \\
\hline Significance level of Chaw test $=0.000$ & & \multicolumn{3}{|c|}{ Significance level Hauseman test $=0.000$} \\
\hline
\end{tabular}

The results of the above table indicate that the amount of net profit has a direct significant relationship with firm's stock returns. Meanwhile, the variable of auditor industry specialization has not significantly affected stock returns, and the moderating role of auditor industry specialization is also rejected. Thus, the first hypothesis is not acceptable. Therefore, although the amount of net profit is valued by market, auditor industry specialization, as one of the most important criteria for audit quality, does not affect the valuation.

The results of estimates of models four and seven have been presented in Table 2 in order to investigate the impact of total accruals and firm's operating cash flow on its stock returns, as well as on the moderating impact of auditor industry specialization.

Table 2. Estimates of models four and seven

\begin{tabular}{|c|c|c|c|c|}
\hline Variable & Coefficient & Significance & Coefficient & Significance \\
\hline Intercept & -0.004 & 0.835 & -0.051 & 0.276 \\
\hline Total accruals & 0.308 & 0.014 & 0.671 & 0.034 \\
\hline Operating cash flow & 1.015 & 0.000 & 1.32 & 0.000 \\
\hline $\begin{array}{l}\text { Auditor industry } \\
\text { specialization }\end{array}$ & - & - & 0.071 & 0.178 \\
\hline $\begin{array}{l}\text { Total accruals* auditor } \\
\text { industry specialization }\end{array}$ & - & - & -0.471 & 0.176 \\
\hline $\begin{array}{l}\text { Operating cash flow* } \\
\text { auditor industry } \\
\text { specialization }\end{array}$ & - & - & -0.442 & 0.141 \\
\hline \multicolumn{5}{|c|}{ Model four } \\
\hline F statistics $=33.545$ & & & \multicolumn{2}{|c|}{ Adjusted R-square $=0.284$} \\
\hline Significance level $=0.000$ & & & \multicolumn{2}{|c|}{ Durbin-Watson statistics $=2.038$} \\
\hline Significance level of Cha & est $=0.000$ & & \multicolumn{2}{|c|}{ Significance level Hauseman test $=0.000$} \\
\hline \multicolumn{5}{|c|}{ Model seven } \\
\hline F statistics $=12.518$ & & & \multicolumn{2}{|c|}{ Adjusted R-square $=0.276$} \\
\hline Significance level $=0.000$ & & & \multicolumn{2}{|c|}{ Durbin-Watson statistics $=2.026$} \\
\hline Significance level of Cha & est $=0.000$ & & \multicolumn{2}{|c|}{ Significance level Hauseman test $=0.000$} \\
\hline
\end{tabular}

The results of Table 2 show that total amounts of accruals and operating cash flow are directly and significantly related to firm's stock returns. Meanwhile, the variable of auditor industry specialization has not significantly affected stock 
returns, and also the moderating role of the auditor is rejected. Thus, total amounts of accruals and operating cash flow are valued by market, but this valuation is not affected by auditor industry specialization.

The results of estimates of models five and eight are presented in Table 3 in order to investigate the impact of discretionary accruals, non-discretionary accruals, and firm's operating cash flow on its stock returns, as well as on the moderating impact of auditor industry specialization.

Table 3. Estimates of models five and eight

\begin{tabular}{|c|c|c|c|c|}
\hline Variable & Coefficient & Significance & Coefficient & Significance \\
\hline Intercept & -0.023 & 0.3 & -0.107 & 0.033 \\
\hline Discretionary accruals & 1.06 & 0.006 & 2.166 & 0.004 \\
\hline Non-discretionary accruals & 0.209 & 0.219 & 0.205 & 0.553 \\
\hline Operating cash flow & 1.773 & 0.000 & 3.035 & 0.000 \\
\hline Auditor industry specialization & - & - & 0.117 & 0.037 \\
\hline $\begin{array}{l}\text { Discretionary accruals* auditor } \\
\text { industry specialization }\end{array}$ & - & - & -1.597 & 0.074 \\
\hline $\begin{array}{l}\text { Non-discretionary accruals* auditor } \\
\text { industry specialization }\end{array}$ & - & - & 0.029 & 0.941 \\
\hline $\begin{array}{l}\text { Operating cash flow* auditor industry } \\
\text { specialization }\end{array}$ & - & - & -1.838 & 0.055 \\
\hline \multicolumn{5}{|c|}{ Model five } \\
\hline F statistics $=25.253$ & & \multicolumn{3}{|c|}{ Adjusted R-square $=0.293$} \\
\hline Significance level $=0.000$ & & \multicolumn{3}{|c|}{ Durbin-Watson statistics= 2.049} \\
\hline Significance level of Chaw test $=0.000$ & & \multicolumn{3}{|c|}{ Significance level Hauseman test $=0.000$} \\
\hline \multicolumn{5}{|c|}{ Model eight } \\
\hline F statistics $=10.205$ & & \multicolumn{3}{|c|}{ Adjusted R-square $=0.284$} \\
\hline Significance level $=0.000$ & & \multicolumn{3}{|c|}{ Durbin-Watson statistics $=2.045$} \\
\hline Significance level of Chaw test $=0.000$ & & \multicolumn{3}{|c|}{ Significance level Hauseman test $=0.000$} \\
\hline
\end{tabular}

The results of Table three indicate that discretionary accruals and operating cash flow have a direct significant relationship with firm's stock returns. However, the variable of non-discretionary accruals does not have a significant impact on stock returns. It should be noted that based on the results of the above table, auditor industry specialization cannot moderate market valuation of earnings components.

\section{Additional analysis}

In order to obtain more information about the moderating role of audit quality, the variable of audit firm's size is used as an alternative for auditor industry specialization. If the audit firm is an audit organization, the variable of firm's size will be one, otherwise, it will be zero. Audit Organization is the biggest audit firm in Iran which owns a large part of Iran's audit market, and is distant from other audit firms in Iran in terms of income.

Using the variable of audit firm's size, the result of estimates of models six, seven, and eight are presented in Table four. 
Table 4. Estimates of models six, seven, and eight

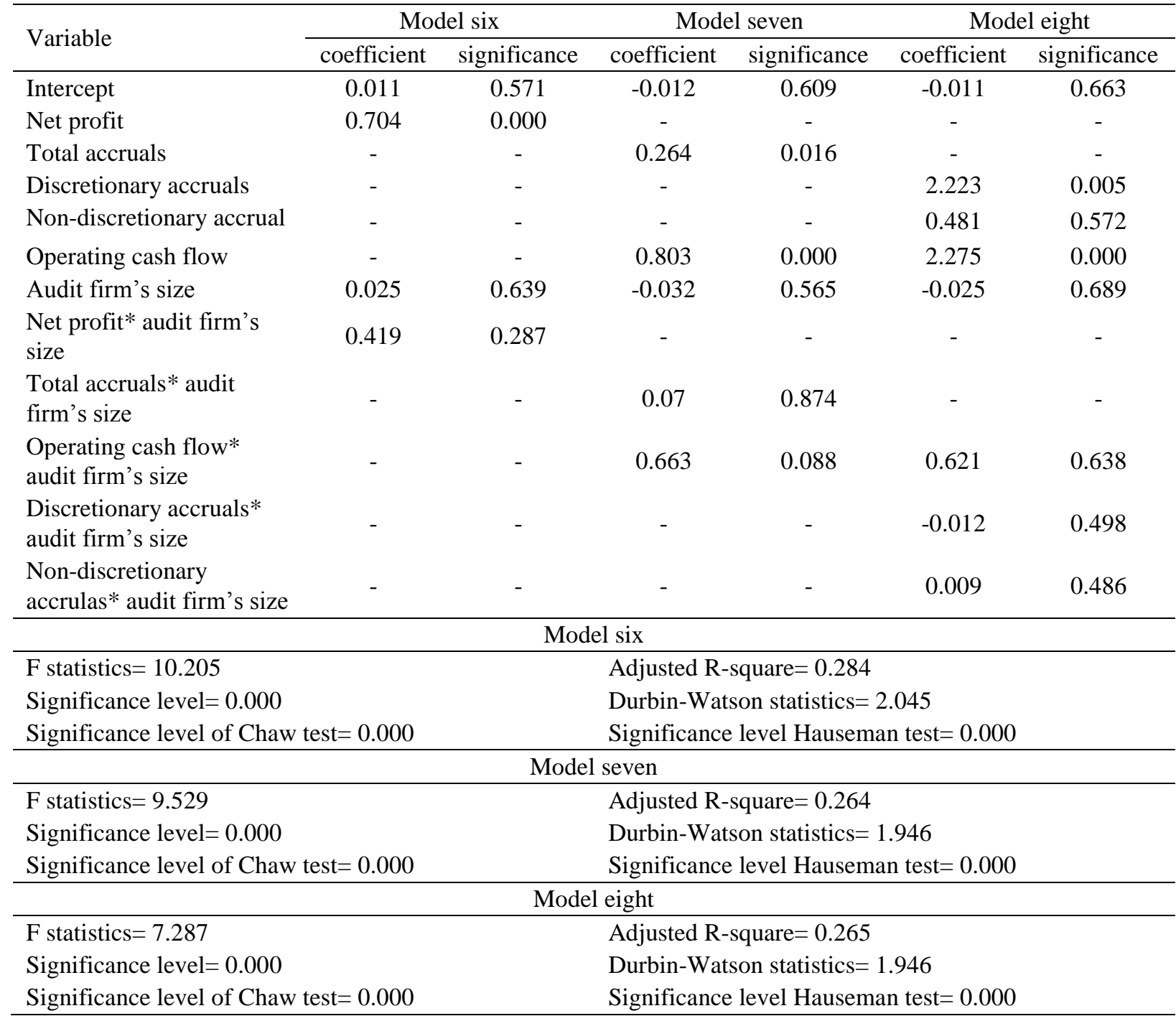

The results of Table 4 indicate that audit firm's size, as one of the criteria of audit quality, dose note affect the relationship between earnings and its components with stock returns. Thus, once again, the role of audit quality in market valuation of earnings and its components is rejected. Given the results of this study, it can be said that Iran's capital market pay considerable attention to earnings and earnings components, including total accruals, discretionary accruals, and operating cash flow. However, audit quality criteria, including auditor industry specialization and audit firm's size do not influence this relationship.

\section{Conclusion}

One of the important questions in accounting studies, is the role of accounting earnings in valuating securities. Prior evidence indicates that accruals earnings plays an important role in valuation process, because it mitigates the problems of scheduling and mismatches lie in the amounts of cash. However, the reliability and usefulness of accruals is in doubt, because managers can manipulate them to make the reported earnings consistent with the accepted principals of accounting and to adjust them as they desire. If management manipulates earnings opportunistically, this management's authority can distort earnings. On the other hand, management can increase information content of earnings through allowing the spread of confidential information. Auditors play a prominent role in reducing the noise of discretionary accrual resulting from opportunistic manipulation of accruals. Thus, audit quality can affect the valuation of discretionary accruals. Meanwhile, industry specialist auditors present high quality audit to their clients, and as a result increase accounting information quality. The reason is that specialist auditors have more knowledge and experience than non-specialist auditors. Given the above explanations, this study attempted to use the data of firms listed in Tehran Stock Exchange to test the foregoing relationships. The results showed positive market valuation of 
earnings and earnings components (including total accruals, discretionary accruals, and operating cash flow). However, the moderating role of auditor industry specialization and the size of the audit firm valuation was not confirmed in this valuation. Thus, it can be deduced that in firms listed in Tehran Stock Exchange, investors pay considerable attention to earnings and its components and does not pay significant attention to audit type. Therefore, the relationship between total accruals and discretionary accruals with stock returns cannot be considered as an instance of signaling theory, because it does not consider audit quality as a tool to reduce the noise of discretionary accruals resulting from opportunistic manipulation of accruals. It is worth mentioning that positive market valuation of earnings and earnings components (including total accrual, discretionary accruals and operating cash flow) which have been inferred in this study are in conformity with the results and arguments of Jones (1991), Sabramanyam (1996), and Arabmazar Yazdi et.al (2006). However, inferring the lack of impact of audit quality on the relationship between earnings and its components with stock returns is in conflict with findings and arguments of Krishnan (2003), Gaul et.al (2003), ), Gaul et.al (2010), and are in conformity with the result of Habib et.al (2014)'s study. While confirming positive market valuation of earnings and earnings components, they stated that Big 4 audit firms do not play a significant role in market valuation of financial items to benefit clients. In addition, they reported the negative impact of Top Ten local audit firms on earnings valuation in China. According to the results of this study, investors in listed firms in Tehran Stock Exchange are suggested to pay more attention to the role of audit quality in order to obtain useful information and attract the information content of earnings and its components and to separate the noise of discretionary accruals from their information content due to the status of audit quality of firm's financial information. Interested researchers are also recommended to reassess the models used in this study by using other criteria for measuring audit quality, earnings management, and market response.

\section{References}

Arab Mazar Yazdi, M., Mashayekhi, B. \& Rafi'ee, A. (2006). Informativeness of cash flows and accruals in Iran Capital Market. Accounting and Auditing Studies, 43, 99-118.

Balsam, S., Krishnan, J. \& Yang, J. S. (2003). Auditor industry specialization and earnings quality. Auditing: A Journal of Practice and Theory, 22, 71-97. http://dx.doi.org/10.2308/aud.2003.22.2.71

DeAngelo, L. E. (1981). Auditor Size and Audit Quality. Journal of Accounting and Economics, 3(3), 183-199. http://dx.doi.org/10.1016/0165-4101(81)90002-1

Becker, C.L., DeFond, M.L., Jiambalvo, J. \& Subramanyam, K.R. (1998). The effect of audit quality on earnings management. Contemporary Accounting Research, 15(1), http://dx.doi.org/10.1111/j.1911-3846.1998.tb00547.x

Dechow, P.M., Sloan, R. \& Sweeny, A. (1995). Detecting earnings management. The Accounting Review, 70(2), 193-226.

Dunn, K.A. \& Mayhew, B.W. (2004). Audit firm industry specialization and client disclosure quality. Review of Accounting Studies, 9, 35-58. http://dx.doi.org/10.1023/B:RAST.0000013628.49401.69

Etemadi, H., Mohammadi, A. \& Nazemi Ardekani, M. (2009). Investigating the relationship between auditor industry specialization and audit quality in firms listed in Tehran Stock Exchange. Journal of Financial Accounting Studies, 1(1 and 2), 17-32.

Gul, F.A., Jeong-Bon, K. \& Qiu, A. (2010). Ownership concentration, foreign shareholding, audit quality, and stock price synchronicity: evidence from China. Journal of Financial Economics, 95(3), 425-442. http://dx.doi.org/10.1016/j.jfineco.2009.11.005

Gul, F.A., Sun, S.Y.J. \& Tsui, J.S.L. (2003). Audit quality, earnings, and the Shanghai stock market return. Journal of Accounting Auditing \& Finance, 18(3), 411-427.

Habib, A. \& Bhaiyan, M.B. (2011). Audit firm industry specialization and the audit report lag. Journal of International Accounting, Auditing and Taxation, 20, 32-44. http://dx.doi.org/10.1016/j.intaccaudtax.2010.12.004

Habib, A., Jiang, H. \& Zhou, D. (2014). Audit quality and market pricing of earnings and earnings components in China. Asian Review of Accounting, 22(1), 20-34. http://dx.doi.org/10.1108/ARA-05-2013-0034

Healy, P. \& Palepu, K. (1993). The effect of firms' financial disclosure policies on stock prices. Accounting Horizons, 7, 1-11.

Jones, J. (1991). Earnings management during import relief investigations. Journal of Accounting Research, 29(2), 193-228. http://dx.doi.org/10.2307/2491047 
Kothari, S.P., Leone, A.J. \& Wasley, C.E. (2005). Performance matched discretionary accrual measures. Journal of Accounting \& Economics, 39(1), 163-197. http://dx.doi.org/10.1016/j.jacceco.2004.11.002

Krishnan, G. (2003). Audit quality and the pricing of discretionary accruals. Auditing: A Journal of Practice and Theory, 22 (March), 109-126. http://dx.doi.org/10.2308/aud.2003.22.1.109

Kwon, S.Y., Lim, C.Y. \& Tan, P. (2007). Legal systems and earnings quality: the role of auditor industry specialization. Auditing: A Journal of Practice and Theory, 26, 25-55. http://dx.doi.org/10.2308/aud.2007.26.2.25

Lin, Z., Jiang, Y. \& Xu, Y. (2011). Do modified audit opinions have economic consequences? Empirical evidence based on financial constraints. China Journal of Accounting Research, 4, 135-154. http://dx.doi.org/10.1016/j.cjar.2011.06.004

Maham, K., Ali Pour, S. \& Talebi, B. (2013). The relationship between earnings management and market performance of firms distributing shere profit. Quarterly of Emperical Studies of Accounting, 3(1), 219-240.

Mascarenhus, D., Cahan, S. \& Naiker, V. (2010). The effect of audit specialists on the informativeness of discretionary accruals. Journal of Accounting, Auditing and Finance, 25(1), 53-84.

Newman, D.P., Patterson, E.R. \& Smith, J.R. (2005). The role of auditing in investor protection. The Accounting Review, 80(1), 289-313. http://dx.doi.org/10.2308/accr.2005.80.1.289

Rahnamaye Roodposhti, F., Pour Zamani, Z., Royaee, R. \& Fazeli, N. (2014). Testing the approach of earnings management efficiency and its role in creating value. Quarterly of Emperical Studies of Accounting, 3(3), 159-177.

Sami, H. \& Zhou, H. (2008). Do auditing standards improve the accounting disclosure and information environment of public companies? Evidence from the emerging markets in China. The International Journal of Accounting, 43(2), 139-169. http://dx.doi.org/10.1016/j.intacc.2008.04.003

Subramanyam, K.R. (1996). The pricing of discretionary accruals. Journal of Accounting and Economics, 22(1/3), 249-281. http://dx.doi.org/10.1016/S0165-4101(96)00434-X

Sun, J. \& Liu, G. (2013). Auditor industry specialization, board governance, and earnings management. Managerial Auditing Journal, 28(1), 45-64. http://dx.doi.org/10.1108/02686901311282498

Tavakolnia, E., Ahmadpour, A. \& Masoomi, T. (2015). Investigating the Moderating Effect of Auditor industry specialization on the Relationship between Board Governance and Accruals Based Earnings Management: Empirical Evidence from Companies Listed in Tehran. 4(15), 93-106.

Tavakolnia, E., Rahimian, N. \& Karamlou, M. (2014). Qualified Audit Opinion and Debt Maturity Structure. The Financial Accounting and Auditing Research, 5(20), 157-180.

Zhou, H. (2007). Auditing standards, increased accounting disclosure, and information asymmetry: evidence from an emerging market. Journal of Accounting and Public Policy, 26(5), 584-620. http://dx.doi.org/10.1016/j.jaccpubpol.2007.08.004

\section{Note}

Note 1. DeAngelo (1981) defines audit quality as the market-assessed joint probability that a given auditor will both detect material misstatements in the client's financial statements and report the material misstatements. 